\title{
Possibilities and restrictions of heavy-mineral analysis for the reconstruction of sedimentary environments and source areas
}

\author{
A.N. Derkachev*, N.A. Nikolaeva \\ V.I. Il'ichev Pacific Oceanological Institute, Far Eastern Branch, Russian Academy of Sciences (POI FEB RAS), \\ Vladivostok, Russia \\ *Corresponding author; e-mail: derkachev@poi.dvo.ru
}

\begin{abstract}
The possible reconstruction of ancient sedimentary environments on the basis of heavy-minerals assemblages is presented by means of discriminant lithogeodynamic diagrams that compare modern and ancient sedimentary environments. This is exemplified by Mesozoic-Cenozoic deposits recovered from ODP cores obtained from the Philippine and Japan Seas, the Japan Trench and the North Atlantic, as well as by deposits from folded areas onshore. On the basis of the comparative analysis, it can be deduced that the main tendencies in mineral assemblages of modern deposits that depend on the structural-tectonic conditions, are fairly well preserved in Cenozoic deposits (including the deposits recovered by ODP drilling). On the other hand, the environmental reconstruction of folded and faulted pre-Cenozoic continental areas on the basis of their heavy-mineral assemblages, by comparing them with supposed modern analogs, is not always possible with much certainty. The main reasons may be either a considerable change in the composition of the initial (primary) mineral assemblages as a result of intralayer solution or the absence, at the time of deposition, of geodynamic environments that closely resembled modern ones.
\end{abstract}

Key words: heavy-mineral assemblages, sedimentary environments, ODP cores, Mesozoic folded belts

\section{Introduction}

Heavy-mineral assemblages now are considered of great importance for characterising the geological context of sedimentary basins of different ages. For the purpose, numerous questions have to be considered, however, from the quantitative distribution of minerals in deposits with different ages to detailed analyses of the minerals' morphology and chemical composition. An excellent work considering the great majority of such topics was published by Mange \& Wright (2007).
Specific aspects of heavy-mineral assemblages in modern marine basins were studied by numerous authors (e.g. Derkachev \& Nikolaeva, 2007, 2010). These studies showed that the heavy minerals inherit many features of the original rock types, irrespective of morphology and climate during sedimentation, i.e. structural and tectonic control is most important. Extensive analyses of the heavy-mineral assemblages in modern marine deposits thus yielded general characteristics that can be used as a basis for the construction of diagrams (named 'lithogeodynamic diagrams' by Derk- 

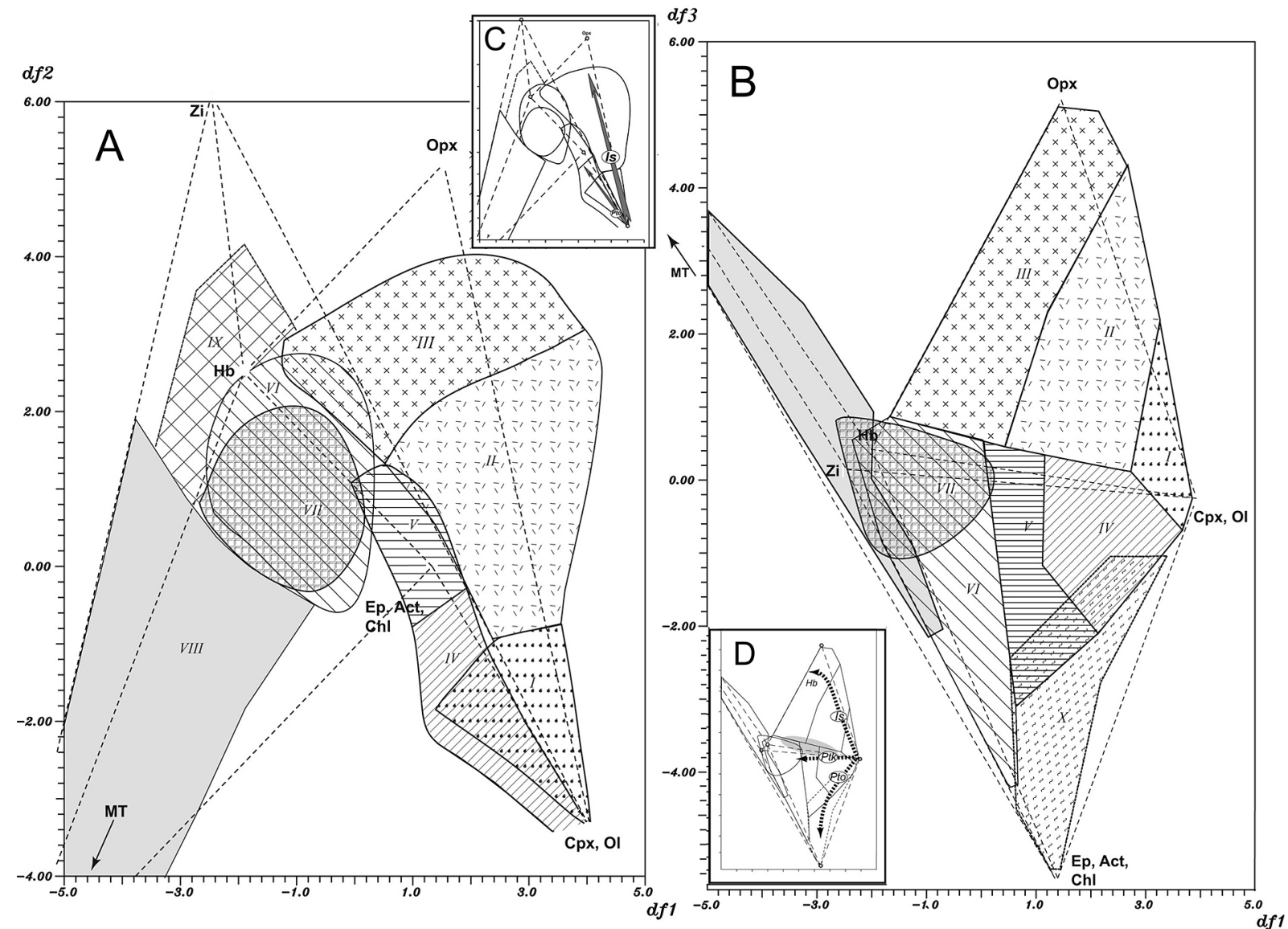

Fig. 1. Lithogeodynamic diagrams reflecting the dependence of heavy-mineral assemblages on the geotectonic setting of the sedimentary basins involved (after Derkachev \& Nikolaeva, 2007; 2010).

$\mathrm{I}-\mathrm{VIII}$ = fields for heavy-mineral assemblages in sediments from different types of geodynamic environments. I = ensimatic island arcs on an oceanic basement (Idzu-Bonin, Mariana, New-Hebrides, Tonga-Kermadek); II-III = developing and mature (ensialic) island arcs (Kuril-Kamchatka, Japanese, Aleutian, Ryukyu, Sunda, New-Zealand, Philippine, New-Guinea); II = mainly clinopyroxene/orthopyroxene associations; III = mainly orthopyroxene/ hornblende associations; IV = young folded areas with evolving primary Cenozoic volcanogenic and volcanogenic-sedimentary rocks, along with areas of active tectonics and magmatism with Pliocene-Quaternary effusive basaltic volcanism, forming thick covers of plateau basalts (environments of both intra-plate tectonic tension and intra-oceanic rises and islands); $\mathrm{V}=$ Meso-Cenozoic marginal-continental volcanic belts; $\mathrm{VI}=$ ancient folded belts of various nature and of different age with primary sedimentary, granitic and metamorphic rocks; VII = Precambrian cratons and intermediate massifs comprising granitic and metamorphic complexes; VIII = ancient platforms; IX $=$ field of the mineral assemblages with large proportions of stable minerals (predominantly zircon) formed by hydraulic differentiation; $X=$ field of heavy-mineral assemblages formed by destruction of altered ultrabasic rocks, including ophiolites.

The position of the hypothetical mineral assemblages with $100 \%$ clinopyroxene and olivine (Cpx, Ol), orthopyroxene $(\mathrm{Opx})$, brown-green and green hornblende $(\mathrm{Hb})$, zircon, apatite, titanite $(\mathrm{Zi})$, the group of the greenschist-facies metamorphic minerals (epidote, chlorite, actinolite: Ep, Act, $\mathrm{Chl}$ ), the group of high-grade metamorphic minerals (tourmaline, rutile, anatase, kyanite, staurolite, sillimanite, andalusite, calcite: MT).

The most typical trends in the distribution of heavy-mineral assemblages in modern sedimentary basins that represent various geodynamic environments are shown on insets C and D: Is = island-arc; Pto = intra-plate oceanic; PtK

$=$ intra-plate continental.

The equations of the discriminant functions are:

$d f_{1}=-5.678 x_{1}-5.703 x_{2}-5.738 x_{3}-5.659 x_{4}-5.705 x_{5}-5.78 x_{6}-5.743 x_{7}-5.742 x_{8}+571.785$

$d f_{2}=-59.797 x_{1}-59.714 x_{2}-59.739 x_{3}-59.717 x_{4}-59.764 x_{5}-59.825 x_{6}-59.704 x_{7}-59.674 x_{8}+5976.46 ;$

$d f_{3}=-30.154 x_{1}-30.098 x_{2}-30.147 x_{3}-30.059 x_{4}-30.206 x_{5}-30.108 x_{6}-30.149 x_{7}-30.139 x_{8}+3015.14$

where $x_{1}=$ the sum of clinopyroxene and olivine, $x_{2}=$ orthopyroxene, $x_{3}=$ brown-green and green hornblende, $x_{4}$ $=$ brown hornblende and oxyhornblende, $x_{5}=$ the sum of epidote, actinolite and chlorite, $x_{6}=$ the sum of garnet, anatase, rutile, staurolite, andalusite, corundum, sillimanite, tourmaline and calcite, $x_{7}=$ the sum of zircon, titanite and apatite, $x_{8}=$ the sum of alkaline pyroxene and alkaline amphibole. 
Fig. 2. Locations of the areas under study.

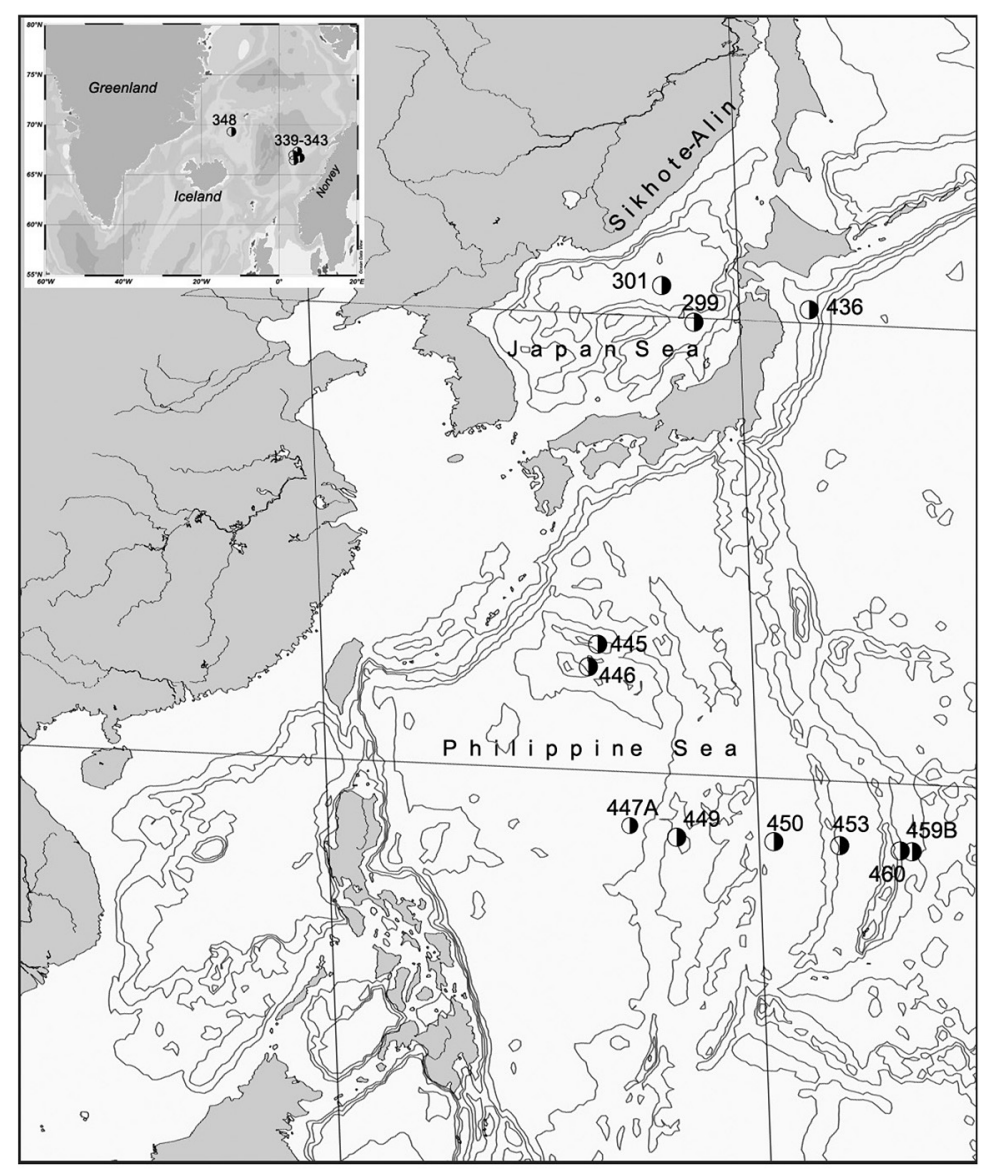

achev \& Nikolaeva, 2007, 2010) that reveal the structural and tectonic context of sedimentary basins (Fig. 1).

The deposits of sedimentary basins undergo commonly essential changes during diagenesis (see, among others, Pettijohn, et al., 1972; Van Loon, 1972/1973; Kholodov, 1983; Morton, 1984; Berger, 1986; Mange \& Maurer, 1992; Morton \& Hallsworth, 1994, 1999, 2007; Bateman \& Catt, 2007; Van Loon \& Mange, 2007). The extent of these changes depends on many factors, including the minerals' susceptibility to chemical weathering in situ (see also Van Loon, 2009; Ludwikowska-Kędzia, 2013; Marcinkowski \& Mycielska-Dowgiałło, 2013; Morton et al., 2013; Wachecka-Kotkowska \& Ludwikowska-Kędzia, 2013; Woronko et al., 2013).

As a significant amount of data on the mineral sediment composition from modern marine basins is available, it is interesting to check whether lithogeodynamic diagrams can be reliably applied to estimate the structural and tectonic conditions of sedimentary basins in the older sedimentary record. The identification of sedimentary environments on the basis of heavy-mineral assemblages for marine deposits of different age is considered in Section 2, which deals with Cenozoic deposits from several oceans obtained from cores recovered by ODP drilling, and with Mesozoic-Cenozoic deposits of folded areas (Fig. 2). These objects were chosen purposely as not only detailed descriptions of these deposits (including data on assemblages of heavy minerals), as well as reconstructions of the environmental conditions and sources of the detrital components are available, but also substantive structural and tectonic data of these basins (Markevich et al., 1987, 1997, 2000, 2007; Nechaev, 1987, 1990, 1991; Filippov, 1990, 2001; Nechaev et al., 1996, 1997).

The objective of the present contribution is to assess the possibilities and limitations of applying lithogeodynamic diagrams to the above-mentioned older deposits. 


\section{Results}

\subsection{Marine Cenozoic deposits}

In how far the features of mineral assemblages from modern deposits are preserved in more ancient marine and ocean environments, is discussed here on the basis of an example of Cenozoic deposits recovered by ODP drilling. For reason of comparison, the mineral composition of Cenozoic deposits from some oceanic regions that are characterised by different geodynamic positions, is also evaluated. These regions are the Philippine Sea and the Sea of Japan, slopes of the Japanese deep-sea trenches, and the North Atlantic near Iceland (Fig. 2). The mineralogical analyses are taken from previous publications (Emelyanov et al., 1978; Murdmaa, Kasakova, 1980; Nesterova et al., 1978; Sato, 1980; Nechaev, 1987, 1990, 1991).

\subsubsection{The Philippine Sea}

The mineral assemblages of the Philippine Sea as a whole reflect environments of convergent continental margins; two trends in the heavy-mineral distribution appear present for the modern sedimentary environments (island-arc and intra-plate oceanic) (Figs 1, 3). The trend for the island-arc is characteristic of deposits on the slopes of the Mariana island arc (Sites 459B, 460) and adjacent areas: the West Mariana Trough (Site 453) and the Parese Vela Basin (Site 450, partly 449) (Fig. 3). The deposits accumulated in a geodynamic environment corresponding to ensimatic volcanic island arcs, which were generated on the oceanic crust during subduction.

The West Mariana Trough was fed mainly with volcanoclastics derived from the adjacent islands of the Mariana island-arc during all the Cenozoic history that this region developed (Fig. 3). Only some single points in the lithogeodynamic diagram deviate from the island-arc trend, towards the field of intra-plate environments; these points represent deposits from the lower part of the cores, where epidote and chlorite appear that indicate transformation of the original rocks into a green-schist facies. These minerals result from erosion of the oceanic basement at initial stages of the island-arc formation.

The deposits obtained from the cores from the Parese Vela Basin (Sites 449, 450) show both resemblance with the island-arc complexes of the Mariana island arc and some essential differences. The deposits of Site 450, which is located nearby the volcanic front of the arc, have a heavy-mineral composition that most strongly resembles the volcanoclastics of the Mariana island arc: the distribution of the points in the diagram corresponds to the main island-arc trend (Figs 1, 3A). Not only volcanoclastics of the Mariana arc, but also relicts of the late active island arcs of the Kyushu-Palau and West Mariana Ridges were sources of the detrital material; they differ little from the modern volcanic arc of the Mariana Islands with respect to their composition. Increased erosion of the basement rocks can be deduced for the deposits of the lower part of the core (lower part of the Middle Miocene). The points in the diagram representing these deposits indicate considerable divergence from an island-arc trend. More intensive delivery of detrital material set free by erosion of both transformed oceanic basement rocks and volcanogenic rocks of a palaeo-island arc of the Kyushu-Palau Ridge occurred in the western part of the basin (Site 449).

\subsubsection{The West Phillippine Basin}

The heavy-mineral assemblages in the cores from the West Philippine Basin (Site 447A) find their places in the lithogeodynamic diagram aligned on an oceanic intra-plate trend (Fig. $3 \mathrm{~A})$. The sources may be both outcrops of oceanic basement and large shield volcanoes. Such volcanoes are known from the Kyushu-Palau palaeo-island arc, and the composition of these magmatic rocks is close to that of modern intra-oceanic rises in the central Pacific (Lelikov et al., 1990).

The development of the West Philippine Sea and sources of the supplied detrital material are essentially different from other parts of the sea. This part of the Philippine Sea, which includes a number of rises, represents a relict of an oceanic plate with a peculiar complex of rocks and minerals (Karig, 1971; Uyeda \& 

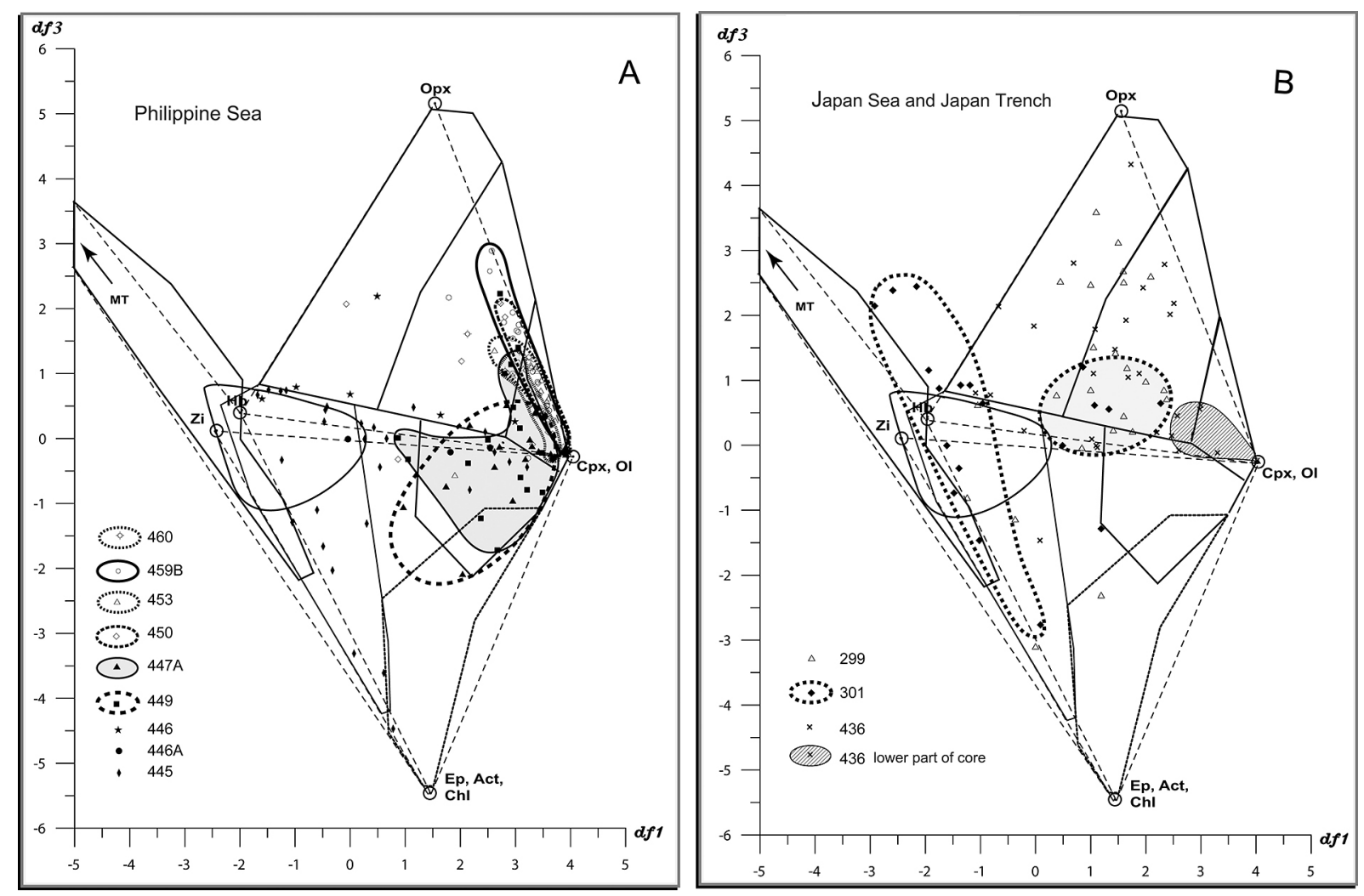

Fig. 3. Position in the lithogeodynamic diagram of the mineralogical assemblages of Cenozoic deposits obtained from ODP cores drilled on a convergent active margin.

Note that rock fragments, unidentifiable grains as well as authigenic and opaque ore minerals were excluded from the total sum, so as to obtain uniform, comparable data on transparent minerals. The sum of the transparent minerals was recalculated to be $100 \%$, and the abundance of each heavy-mineral species was scaled accordingly.

Ben-Avraham, 1972; Sato, 1980; Lelikov et al., 1990; Nechaev, 1991). The configuration of the fields with the points reflecting the heavy-mineral composition in cores from this part of the sea (Sites 445, 446, 446A, 447A) considerably differs from that of typical island-arc complexes. Clear signs of erosion of rocks that are characteristic of intra-oceanic rises are present in the lower, Oligocene part of the core. Nechaev (1991) mentioned high amounts of both low-ferriferous olivine and brown titanic clinopyroxene - characteristic minerals of volcanites from intra-oceanic rises - in these deposits. The peaks in the concentration of green-schist minerals also indicate that during some Cenozoic intervals (Oligocene, Early Miocene) detrital material was delivered by erosion of both magmatic Early Palaeogene rocks and, partially, the oceanic basement. Taken all above evidence together, the comparative data do not contradict the present concepts about the geodynamic development of this part of the Philip- pine Sea (Karig, 1971; Uyeda \& Ben-Avraham, 1972; Sato, 1980; Nechaev, 1991).

\subsubsection{The Japan Trench}

Analysis of the heavy-mineral composition of Cenozoic deposits recovered from cores obtained by drilling on the slope of the Japan Trench (Site 436) and the back-arc basin of the Sea of Japan (Sites 299, 301), showed that island-arc volcanoclastic and volcano-terrigenous material was supplied to these areas during the entire Neogene-Quaternary (Fig. 3B). According to the composition of the heavy-mineral assemblages, the source of the detrital material was a complex of rocks typical for ensialic island arcs (Fig. 1). The detrital material is more femic in composition than that supplied by island arcs (such as the modern Id$\mathrm{zu}-$ Bonin island arc), and it influenced only the composition of the Middle Miocene deposits in the lower part of Site 436. It is characteristic that the intra-plate (oceanic) trend in the distri- 
bution of heavy-mineral assemblages is completely absent in the deposits of Site 436.

Mainly sedimentary material delivered from the continental frame of the Sea of Japan (Figs 1, 3B) contributed to the mineral composition in the central Japan Sea Basin (Site 301). In the diagram (Fig. 3B), the majority of points are grouped in the field of ancient folded areas consisting of granitic-metamorphic and sedimentary rocks. Hornblende and epidote prevail; accessory minerals derived from granitic-metamorphic rocks (zircon, titanite, garnet, apatite) occur in significant amounts, and their concentrations increase in the Neogene deposits of the core. Data from the light rock-forming minerals also indicate a mainly continental source of the detrital material (Sibley \& Pentony, 1978; Packer \& Ingersoll, 1986; Boggs \& Seyedolali, 1992). The supply of volcano-terrigenous material from the Japanese island arc considerably increased in the Pleistocene, most likely by turbidity currents in a submarine canyon. The points characterising these deposits in the lithogeodynamic diagram are concentrated in the field of ensialic island arcs, and they are consistent with the positions of the heavy-mineral assemblages from Site 299 (Fig. 3B).

\subsubsection{The North Atlantic}

A last example concerns basins developing in another geodynamic environment (the constructive border of lithosphere plates). Data from Emelyanov et al. (1978) and Nesterova et al. (1978) are taken here as a basis. The evolution of the heavy-mineral composition in Palaeogene-Quaternary deposits from cores 348 (from a basin within the Iceland plateau, North Atlantic) and 339-343 (the Voring plateau off the coast of Norway) is shown in Figure 4 . The heavy-mineral assemblages of these North Atlantic regions essentially differ from each other in lithogeodynamic diagrams. Clear indications of an influence of intra-plate environments are present in the deposits of the Iceland plateau, especially in Middle Miocene-Pliocene deposits. At Site 348, located fairly close to a spreading axis, the mineral assemblages are characterised by a more femic composition (a volcanogenic detrital mineral complex prevails), and on the Voring plateau (Sites 339-343) they are presented by a sialic mineral group of terrigenous nature. The trend of an increasing quantity of volcanogenic material from ancient (Oligocene) to younger, with a peak supply during the Middle Miocene-Pliocene, is characteristic of deposits from Site 348. However, some differences caused by the structural and tectonic evolution of these sedimentary basins are present in spite of the prevailing volcanogenic components in the mineral composition.

The points of the heavy-mineral composition in the lithogeodynamic diagram distinctly show different mineral assemblages for the Oligocene-Early Miocene, the Middle Miocene-Pliocene, and the Pleistocene, respectively. As a whole, they are consistent with the mineral complexes described by Nesterova et al. (1978). The Oligocene-Early Miocene deposits are characterised by exclusively terrigenous sialic assemblages of detrital minerals; hornblende and epidote dominate, with considerable contributions of accessory minerals from granitic-metamorphic rocks. The majority of points of this heavy-mineral complex are grouped in the fields of both ancient folded belts and outcrops of the crystalline basement (shields). Additional evidence for a terrigenous source of the detrital material comes from comparison of these mineral assemblages with those of deposits from the Voring plateau (Sites 339-343), which were affected by the supply of clastic material from the coast of Norway throughout the Cenozoic (from the Eocene to the Holocene). Figure 4 shows that the points of representing the heavy-mineral assemblages from the cores are entirely restricted to a field characterising sedimentary basins conjugated with ancient folded areas and the shields. Apparently, they are partially overlapped by fields characterising heavy-mineral assemblages of Oligocene-Lower-Miocene deposits from Site 348; this supports that their source areas resemble each other regarding their composition.

The phase of strongly increased volcanic activity in the region, first of all in Iceland, started in the Middle Miocene and is still continuing nowadays; it is reflected by a change in the heavy-mineral composition at Site 348 . The majority of points characterising the mineral composition in the deposits of this age are located 
Fig. 4. Position in the lithogeodynamic diagram of mineralogical assemblages of Cenozoic deposits obtained from ODP-cores drilled in different geodynamic environments (Northern Atlantic).

Numbers in dark circles denote average values of the North Atlantic Quaternary deposits for the following mineralogical provinces: 1 = Icelandic, 2 = Jan-Mayen, 3 = Farer, 4 = central Greenland, 5 = Norwegian, 6 = West European. After Kharin et al. (1979) and Emelyanov \& Kharin (1982). See also the notes in the caption of Figure 3.

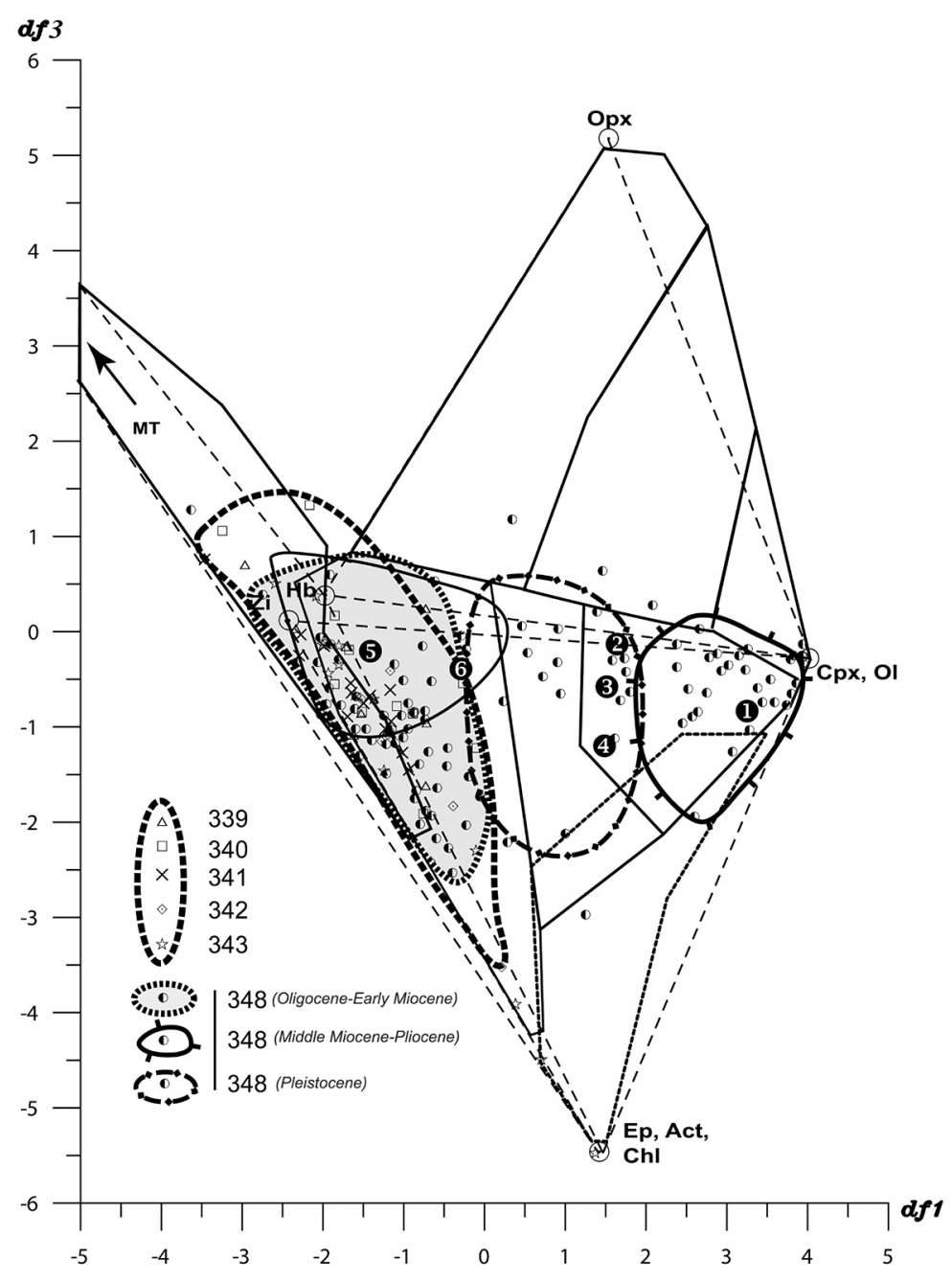

in the field of intra-plate environments, with a primary influence of a basalt magmatism of tholeiitic rock series. The points representing the average values of the heavy-mineral assemblages from modern mineralogical provinces (Iceland, Farer and Jan-Mayen Islands, and central Greenland) also concentrate in this field (Kharin et al., 1979; Emelyanov \& Kharin, 1982).

The global deterioration of the climate that took place during the Pleistocene caused both cooling and the formation of thick landice masses. This resulted in an increase in the supply of terrigenous material to deep-water regions of North Atlantic by icebergs. This is reflected by an increase in the amount of terrigenous clastics in the mineral complexes of Pleistocene deposits, resulting in mixed volcanogenic-terrigenous mineral assemblages. The points representing the heavy-mineral assemblages of this age in the diagram, show displacement to the left from typical representatives of intra-plate environments (Fig. 4).

\subsubsection{Conclusions regarding the Cenozoic marine deposits}

Analysis of the above data shows that the main tendencies regarding the heavy-mineral assemblages depend primarily on the structural and tectonic context of the sedimentary basins, as the characteristics of modern deposits are preserved in the Cenozoic deposits recovered from ODP cores.

\subsection{Mesozoic-Cenozoic marine deposits of continental folded belts}

Some parts of Sikhote Alin' are suitable examples for assessment of the practical applicability of diagnostic aspects of heavy-mineral 
assemblages to the analysis of ancient deposits which form part of complicated folded and folded/faulted terrestrial complexes. Extensive material, including data on the heavy-mineral composition of such complexes, as well as palaeogeodynamic reconstructions form the basis for this investigation (Markevich et al., 1987, 1997, 2000; 2007; Filippov, 1990, 2001; Nechaev et al., 1996, 1997; Filippov et al., 2000).

The folded Sikhote-Alin' area is nowadays considered to represent a complicated accretionary-collision structure consisting of genetically heterogeneous crust fragments (terrains) of different ages. Structural complexes of the continental margin, island arcs and the ocean are tectonically combined there (e.g. Khanchuk et al., 1988; Markevich et al., 1997, 2000; Natalyin, 1991; Simanenko, 1991; Zyabrev, 1994; Filippov et al., 2000; Filippov, 2001).

Geological data (including the deposits' composition) indicate that the Early Cretaceous sedimentary basins that now form part of the folded Sikhote-Alin' area, were filled with detrital material from source areas with a mature continental crust. Volcanogenic sources were of secondary importance only. The heavy-mineral compositions indicate derivation from sialic material, characteristic of granitic-metamorphic rocks. The great majority is represented by the most stable species, mainly zircon, which constitutes in many samples $90 \%$ or even more (e.g. Ageeva, 1960, 1971; Markevich et al., 1987, 1997, 2000, 2007; Nechaev et al., 1996, 1997; Filippov, 1990, 2001; Filippov et al.,2000). Such high concentrations of ultrastable minerals in combination with fairly low contents of hornblendes (which are one of leading components in mineral assemblages of acid magmatic and metamorphic rocks) are evidence of changes due to intralayer solution of part of the unstable minerals.

In comparison with heavy-mineral assemblages of modern sedimentary basins in marginal seas, the Sikhote-Alin' deposits differ essentially (Fig. 5A, B). The majority of points are situated in the field with a high content of stable minerals, which is not characteristic of modern marine deposits: only a few of the available thousands of analyses are found in this field (Fig. 5 C, D); they characterise coast- al-marine deposits of areas where thick weathered crusts of granitoids are eroded under the conditions of a humid tropical climate. It has to be mentioned, however, that similar assemblages of stable minerals at a scale of an entire sedimentary basin occupy some insignificant areas, having been replaced by assemblages of unstable minerals during deepening of the sea. Heavy-mineral analysis of modern deposits in basins conjugated with ancient folded areas in which granitoids and sedimentary-metamorphic rocks are widespread, show that in such environments hornblende and epidote-hornblende mineral assemblages with variable amounts of micas and accessory minerals of granitic-metamorphic rocks are commonly formed.

Analysis of the nature of volcanogenic and volcanogenic-sedimentary complexes is important for unravelling both the evolution of ancient sedimentary basins and the formation of the structures in folded-thrust belts. Early Cretaceous volcanogenic-sedimentary complexes of Sikhote Alin' occur jointly as separate fragments; this is most commonly ascribed to successive subduction phases of an accretionary prism (Borukaev \& Natalyin, 1994; Zyabrev, 1994; Markevich et al., 1997, 2000, 2007). These complexes occur in volcanic island-arc systems of two types: epioceanic (generated and developing on an oceanic basement) and epicontinental (generated and developing on a continental basement) (e.g. Markevich et al., 1997, 2000, 2007; Filippov et al., 2000). These researchers also came to the conclusion that Jurassic-Early Cretaceous volcanogenic-siliceous complexes and carbonates, siliceous-clayey and detrital rocks that are associated with them, were formed in intra-plate oceanic environments.

Comparison of the heavy-mineral assemblages in the Mesozoic sedimentary rocks of the folded Sikhote-Alin' area with those in modern deposits from a continent-ocean transitional zone, shows the following (Fig. 5).

1) The identification of intra-plate oceanic environments (volcanogenic-siliceous complexes) as an entity is consistent with the corresponding field in the lithogeodynamic diagram. 

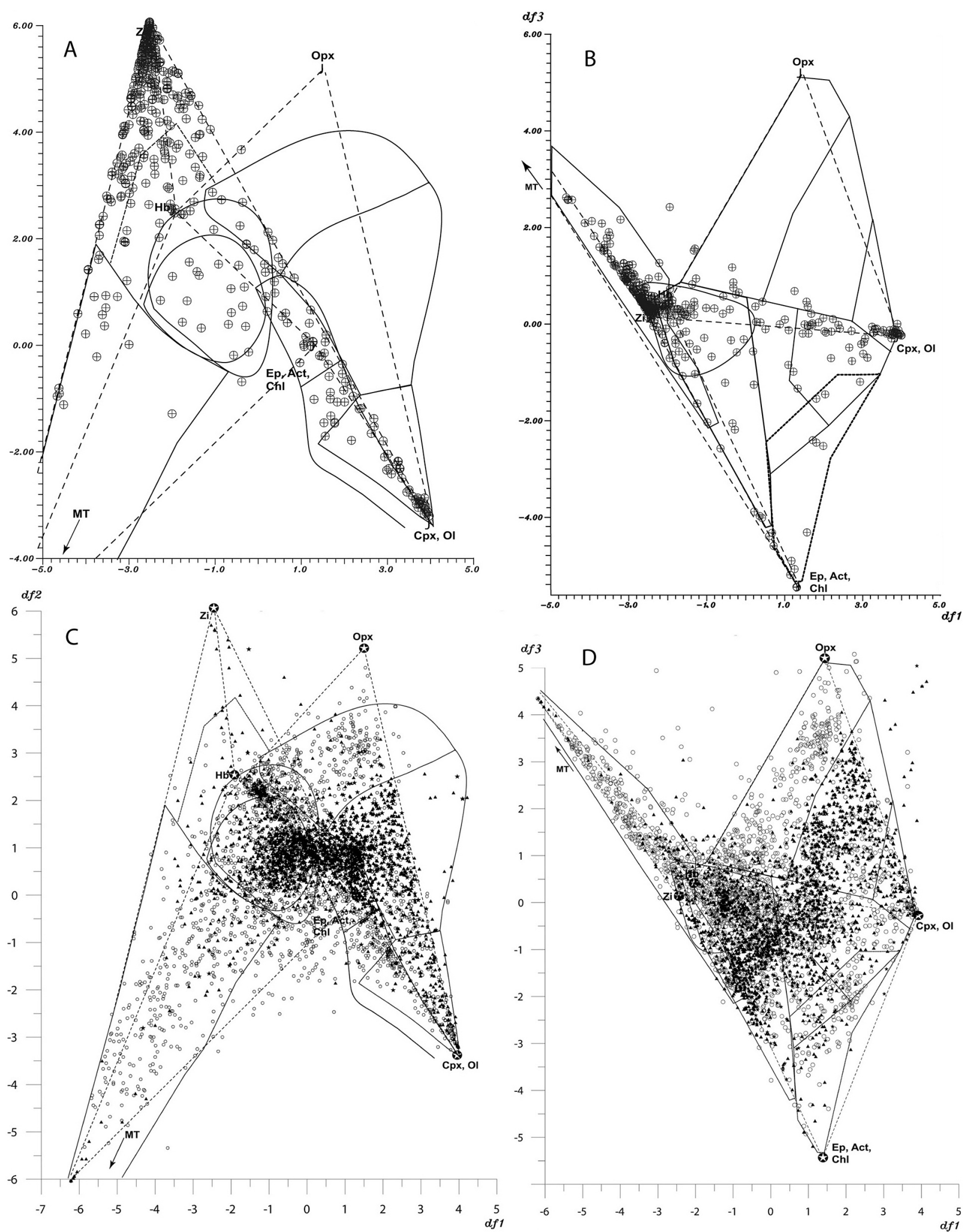

Fig. 5. Comparison of the heavy-mineral compositions of Mesozoic deposits from the folded Sikhote-Alin' belt (A, B) with those from modern marine deposits (C, D) (about 4250 analyses were processed). See also the notes in the caption of Figure 3. 
2) Environments of oceanic volcanic island arcs are recognised with a fairly high degree of certainty, though some deviation from a typical island-arc trend is present in the form of higher proportions of epidote and chlorite (possibly derived from eroded metavolcanites).

3) Attempts to establish the structural and tectonic context of fragments of island-arc systems (for example, the Udylsky and Kemsky terrains), comparable to modern ensialic volcanic island arcs, did not give the results that were hoped for. First of all, there is no typical island-arc configuration in the distribution of heavy-mineral assemblages caused by a clear shortage of orthopyroxenes. In our opinion, it is not truly correct to explain the shortage of orthopyroxenes in the Early-Cretaceous deposits of ensialic island-arc systems only by subduction of lithosphere plates (oblique convergence of plates) (Nechaev et al., 1996; Markevich et al., 1997). For the time being, however, this question remains open; it requires additional investigation. Moreover, the group of stable minerals (mainly zircon) derived from granitic-metamorphic rocks is present in the mineral complexes in appreciable quantity, which is not so clearly the case in modern analogues of such structural and tectonic environments. At least, the individual fragments of the folded Sikhote-Alin' area cannot well be compared with the modern Japanese island-arc system. Considering the heavy-mineral composition of modern deposits in the seas of the continental margins around the Pacific, it was found in almost all areas under study that are environments of ensialic island arcs and active continental margins, a distinct orthopyroxene/clinopyroxene paragenesis that is a characteristic of environments of this type.

\section{Conclusions}

Comparison of the heavy-mineral assemblages shows that the main characteristics of mineral assemblages in modern deposits that depend on their structural-tectonic environment, are largely preserved in Cenozoic deposits (including deposits recovered by ODP drilling). On the other hand, the recognition of the tectonic-structural environment of pre-Cenozoic deposits forming part of folded and folded-thrust continental areas on the basis of comparison of their heavy-mineral assemblages with those of presumed modern analogs is not always unequivocal. The main reasons are either a considerable change in composition of the initial (primary) mineral assemblages as a result of intralayer solution of unstable minerals during diagenesis, or the absence in the geological record of geodynamic environments that are analogous, or close, to the modern ones. This regards in particular the recognition of the tectonic-structural environment of fragments from ensialic island-arc systems in the folded Sikhote-Alin' area. Heavy-mineral assemblages without a clear island-arc configuration are present here, in a form that it is characteristic of modern subduction environments. It supports the assumption that the Early Cretaceous deposits of the folded Sikhote-Alin' area were formed in other tectonic environments, different from modern ensialic island arcs.

It is consequently necessary to interpret the depositional context of sedimentation on the basis of its heavy-mineral composition with utmost care. Particularly diagenetic changes of the initial mineral compositions make the reconstruction of geodynamic environments on the basis of a comparison of the heavy-mineral assemblages with those of presumed modern analogues commonly difficult. Analysis of additional information about the geological context in the form of a detailed analysis of both mineral characteristics and chemical composition becomes then important, too. Yet, an analysis as presented here, in a combination with well-known classification diagrams for light rock-forming minerals, can be useful for the reconstruction of both the structural and the tectonic position of ancient basins and their evolution. 


\section{References}

Ageeva, E.M., 1971. Material composition and postsedimentational changes of rocks from Komsomol series, voleano Lower Cretaceous of the northern Sikhote Alin. Questions of a lithology and geochemistry of volcanogenic-sedimentary formations from the South of the Far East, 81-107 (in Russian).

Ageeva, E.M., 1960. Mineralogy and petrography of the South Primorye Cretaceous deposits. Materials on stratigraphy and lithology of the Far East Mesozoic deposits. Proceedings of Far Eastern office, Siberian Branch, Academy of Sciences, USSR, Series Geology 6, 59-124 (in Russian).

Bateman, R.M., Catt, J.A., 2007. Provenance and palaeoenvironmental interpretation of superficial deposits, with particular reference to post-depositional modification of heavy mineral assemblages. [In:] M.A. Mange \& D.T. Wright (Eds): Heavy minerals in use. Developments in Sedimentology 58, 151-188.

Berger, M.G., 1986. Terrigenous mineralogy. Nedra, Moscow, 226 pp. (in Russian).

Boggs, S.J., Seyedolali, A., 1992. Provenance of Miocene sandstones from sites 796, 797 and 799, Japan Sea. Proceedings of the Ocean Drilling Program, Scientific Results 127/128 1, 99-113.

Borukaev, U.B., Natalyin, B.A., 1994. Accretionary tectonics of the South of the Russian Far East. Geology and Geophysics 35(7-8), 89-93 (in Russian).

Derkachev, A.N., Nikolaeva, N.A., 2007. Multivariate analysis of heavy mineral assemblages of deposits from the marginal seas of the Western Pacific. [In:] M.A. Mange \& D.T. Wright (Eds): Heavy minerals in use. Developments in Sedimentology 58, 439-464.

Derkachev, A.N., Nikolaeva, N.A., 2010. Environmental mineralogical indicators of near-continental sediment formation within Pacific Ocean western part. Dal'nauka, Vladivostok, 321 pp. (in Russian).

Emelyanov, E.M., Blazhchishin, A.I., Kharin, G.S., Lozovaya, N.G., Zangalis, K.P., 1978. Mineral and chemical composition of deposits of the Voring Plateau, DSDP Leg 38. Supplement volums 38, 39, 40, 41. DSDP, 31-54.

Emelyanov, E.M., Kharin, G.S., 1982. A role of volcanism at formation of mineral composition of modern and Late Quaternary deposits from the Northern Atlantic. [In:] G.B. Udintsev (Ed.): Geology of a bottom of the World Ocean. Atlantic. Biostratigraphy and tectonics. Nauka, Moscow, 66-116 (in Russian).

Filippov, A.N., 1990. Formational analysis of Mesozoic deposits in the Western Sikhote-Alin. Far Eastern Branch, Academy of Sciences of the USSR, Vladivostok, 144 pp. (in Russian).

Filippov, A.N., 2001. Jurassic-Early Cretaceous volcanogenic-siliceous complex of the Manoma river (Northern Sikhote Alin): fragment of a sedimentary cover of a paleooceanic plate. Pacific Geology 20(1), 25-38 (in Russian).

Filippov, A.N., Kemkin, I.V., Panasenko, E.S., 2000. Early Jurassic hemipelagic deposits of Samarkinsky terrain (Central Sikhote Alin): structure, composition and environments of sedimentation. Pacific Geology 19(4), 83-96 (in Russian).

Karig, D.E., 1971. Origin and development of marginal basin in the western Pacific. Journal of Geophysical Research 76, 2542-2561.

Khanchuk, A.I., Panchenko, I.V., Kemkin, I.V., 1988. Geodynamic evolution of Sikhote Alin and Sakhalin in the Late Paleozoic and the Mesozoic. Vladivostok, 54 pp. (in Russian).

Kharin, G.S., Emelyanov, E.M., Vasilenko, V.N., Soldatov, A.V., 1979. Mineralogical provinces of the Atlantic Ocean deep-water deposits. Oceanological investigations 26, 49-60 (in Russian).

Kholodov, V.N., 1983. Postsedimentational transformation in elision basins (on an example of the eastern near-Caucasus). Nauka, Moscow, 152 pp. (in Russian).

Lelikov, E.P., Bezverkhny, V.L., S'edin, V.T., Karnaukh, V.N., Malyarenko, A.N., Mel'nichenko, Yu.I., Neverov, Yu.L., 1990. New data on geology of the Philippine Sea (by results of the 30/31 Cruise of R/V "Professor Bogorov" and 29 Cruise of $R / V$ "Pegas"). POI FEB RAS, Vladivostok, 68 pp. (in Russian).

Ludwikowska-Kędzia, M., 2013. The composition of transparent heavy minerals in Quaternary deposits of the Kielce-Łagów valley (Holy Cross Mountains, Poland). Geologos 19 (this issue), 95-129

Mange, M.A., Maurer, H.F.W., 1992. Heavy minerals in colour. Chapman and Hall, London, 147 pp.

Marcinkowski, B. \& Mycielska-Dowgiałło, E., 2013. Heavy-mineral analysis in Polish investigations of Quaternary deposits: a review. Geologos 19 (this issue), 5-23.

Markevich, P.V., Filippov, A.N., Malinovsky, A.I., Mikhaylik, E.V., Kitaev, I.V., Tikhonova, V.I., Trushkova, N.V., 1987. Phanerozoic geosynclinal sedimentation in both Sikhote-Alin and Koryakiya-Kamchatka regions. [In:] E.V. Krasnov (Ed.): Geosynclinal lithogenesis on the boundary between continent and ocean. Nauka, Moscow, 10-134 (in Russian).

Markevich, P.V., Filippov, A.N., Malinovsky, A.I., Zyabrev, S.V., Nechaev, V.P., Vysotsky, S.V., 1997. Cretaceous volcanogenic-sedimentary formations of Lower Priamurye. Dal'nauka, Vladivostok, 300 pp. (in Russian).

Markevich, P.V., Konovalov, V.P., Malinovsky, A.N., Filippov, A.N., 2000. Lower Cretaceous deposits of Sikhote Alin. Dal'nauka, Vladivostok, 283 pp. (in Russian).

Markevich, P.V., Malinovsky, A.I., Tuchkova, M.I., Sokolov, S.D., Grigoryev, V.N., 2007. The use of heavy minerals in determining the provenance and tectonic evolution of Mesozoic and Cenozoic sedimentary basins in the continent-Pacific ocean transition zone: examples from Sikhote-Alin and Koryak-Kamchatka regions (Russian Far East) and western Pacific. [In:] M.A. Mange \& D.T. Wright (Eds): Heavy minerals in use. Developments in Sedimentology 58, 789-822.

Morton, A.C., 1984. Stability of detrital heavy minerals in Tertiary sandstones of the North Sea Basin. Clay Minerals 19, 287-308.

Morton, A.C., Hallsworth, C.R., 1994. Identifying provenance-specific features of detrital heavy mineral 
assemblages in sandstones. Sedimentary Geology 90, 241-256.

Morton, A.C., Hallsworth, C.R., 1999. Processes controlling the composition of heavy mineral assemblages in sandstones. Sedimentary Geology 124, 3-29.

Morton, A.C., Hallsworth, C.R., 2007. Stability of detrital heavy minerals during burial diagenesis. [In:] M.A. Mange \& D.T. Wright (Eds): Heavy minerals in use. Developments in Sedimentology 58, 215-245.

Morton, A., Hounslow, M.W. \& Frei, D., 2013. Heavy-mineral, mineral-chemical and zircon-age constraints on the provenance of Triassic sandstones from the Devon coast, southern Britain. Geologos 19 (this issue), 67-85.

Murdmaa, I., Kazakova, V., 1980. Course-silt fraction mineralogy of Japan Trench deposits. Deep Sea Drilling Project. Legs 56 and 57. Initial Reports DSDP 56-57, part 2, 1005-1009.

Natalyin, B.A., 1991. Mesozoic accretionary and collision tectonics of the Far East South, USSR. Pacific Geology 5, 3-23 (in Russian).

Nechaev, V.P., 1987. Modern sedimentation and volcanism in the Philippine Sea. [In:] E.V. Krasnov (Ed.): Geosynclinal lithogenesis on the boundary between continent and ocean. Nauka, Moscow, 135-167 (in Russian).

Nechaev, V.P., 1990. Reconstruction of geological evolution for the Philippine and Japan seas on detrital components of deposits. Lithogenesis and ore formation in ancient and modern marine basins of the Far East. FEB RAS, Vladivostok, 112-149 (in Russian).

Nechaev, V.P., 1991. Evolution of the Philippine and Japan Sea from the clastic sediment record. Marine Geology 97, 167-190.

Nechaev, V.P., Markevich, P.V., Malinovsky, A.I., et al., 1996. Geodynamic environments at accumulation of Cretaceous deposits in Lower Priamurye on assemblages of heavy minerals. Pacific Geology 3, 14-24 (in Russian).

Nechaev, V.P., Musasino, M., Li, D.-U., 1997. Jurassic-Lower Cretaceous geodynamic evolution of east margin of Asia: reconstruction on change of heavy mineral assemblages from sedimentary rocks. Pacific Geology 16(6), 21-35 (in Russian).

Nesterova, M.P., Scherbakov, F.A., Shevchenko, A.J., Turanskaja, N.W., Kazakova, W.P., Samosudov, A.G., Kuzmina, T.G., Rudakova, A.N., 1978. Origin of the Late Cenozoic deposits of the Icelandic Basin, DSDP Site 348, Leg 38. Supplement volumes 38, 39, 40, 41. DSDP, 73-95.

Packer, B.M., Ingersoll, R.V., 1986. Provenance and petrology of Deep Sea Drilling Project sands and sand- stones from the Japan and Mariana fore-arc and backarc regions. Sedimentary Geology 51, 5-28.

Pettijohn, F.J., Potter, P.E., Siever, R., 1972. Sand and sandstones. Springer Verlag, New York and Berlin, 618 pp.

Sato, Y., 1980. Heavy mineral composition of Tertiary deposits at Deep-Sea Drilling Project Sites 225 and 446. Northeastern Philippine Sea. Initial Reports DSDP 58, 661-668.

Sibley, D.F., Pentony, K.J., 1978. Provenance variation in turbidite deposits, Sea of Japan. Journal of Sedimentary Petrology 48, 1241-1248.

Simanenko, V.P., 1991. Basalt-andesitic assemblages of Paleozoic and Mesozoic island arcs. [In:]: A.D. Shcheglov (Ed.): Pacific Asian margin. Magmatism. Nedra, Moscow, 58-72 (in Russian).

Uyeda, S., Ben-Avraham, Z., 1972. Origin and development of the Philippine Sea. Nature 240, 176-178.

Van Loon, A.J., 1972/1973. "Habitus" of some heavy minerals from the Tertiary of Southern Limburg (The Netherlands). Mededelingen van de Rijks Geologische Dienst, Nieuwe Serie 23, 39-67.

Van Loon, A.J., 2009. Unravelling the enigmas of the "silver sands" in the Dutch/German/Belgian border area. Netherlands Journal of Geosciences 88, 133-145.

Van Loon, A.J., Mange, M.A., 2007. “In situ” dissolution of heavy minerals through extreme weathering, and the application of the surviving assemblages and their dissolution characteristics to correlation of Dutch and German silver sands. [In:] M.A. Mange \& D.T. Wright (Eds): Heavy minerals in use. Developments in Sedimentology 58, 189-213.

Wachecka-Kotkowska, L. \& Ludwikowska-Kędzia, M., 2013. Heavy minerals of the fluvial Pleniglacial deposits of the Piotrków Plateau and the Holy Cross Mountains - a comparative study. Geologos 19 (this issue), 131-146.

Woronko, B., Rychel, J., Karasiewicz, M.T., Ber, A., Krzywicki, T., Marks, L. \& Pochocka-Szwarc, K., 2013. Heavy and light minerals as a tool for reconstruction of depositional environments: an example from the Jałówka site (northern Podlasie region, NE Poland). Geologos 19 (this issue), 47-66.

Zyabrev, S.V., 1994. Early Cretaceous cherts of Kisilevsky-Manominsky terrains - the youngest oceanic deposits in structure of the South of a continental part of the Far East of Russia. Pacific Geology 6, 74-82 (in Russian).

Manuscript received: 23 October 2012 Revision accepted: 26 February 2013 